\title{
Stereotaxic amygdalotomy and basofrontal tractotomy in psychotics with aggressive behaviour
}

\author{
K. VARNET AND ANNA MADSEN \\ From the Department of Neurosurgery, Rigshospitalet, Copenhagen, and Department D, Psychiatric Hospital \\ Sct. Hans, Roskilde, Denmark
}

SUMMARY Twelve patients with personality disorders or chronic schizophrenia in whom aggressivedestructive behaviour was a prominent feature were treated by bilateral stereotaxic electrocoagulation of the amygdala. In two of the patients a cingulectomy and in five of the patients a frontal lobotomy had been performed several years previously without effect. In 11 of the patients the amygdalotomy resulted in disappearance of, or marked reduction in, their aggressive episodes. In two patients with frequent self-mutilations and reactive psychotic episodes these symptoms disappeared after an additional basofrontal tractotomy by Knight's method.

It has been recognized for several years that patients with temporal lobe seizures often have disturbances of emotional and affective behaviour. It is also known that persons with abnormalities of general behaviour, often of a similar pattern, frequently have an abnormal electroencephalogram (Hill, 1952; Gibbs, 1958; Lennox, 1960; Hughes and Schlagehauff, 1961).

Experience with temporal lobe resection in patients with psychomotor seizures has indicated that the behavioural changes are favourably influenced by the operation, in some cases independently of the degree of seizure relief (Milner, 1958; Falconer, 1965).

Experimental evidence accumulated during recent years has further elaborated Papez's (1937) original concept of the role of the limbic system in affectively determined behaviour. More detailed analysis of the frontotemporal portion of the limbic system has identified especially the amygdala complex as the region invclved in emotional expressions of fear and anger (MacLean and Delgado, 1953; Ursin, 1960).

Clinical experience with stereotaxic lesions of the amygdala, in patients with and without recognized temporal lobe epilepsy, has shown that this procedure in a large percentage of cases resulted in a marked reduction in, or abolition of, hostile-destructive episodes and antisocial behaviour (Narabayashi, Nago, Saito, Yoshida, and Nagahata, 1963; Erwin and Belsasso, 1964; Heimburger, Whitlock, and Kalsbeck, 1966). This corresponds with our own experience in a series of 51 patients with psycho- motor seizures with a mesiobasal EEG focus, who were treated by stereotaxic amygdalotomy (Værne⿻ and Andersen, unpublished).

In the present series, stereotaxic amygdalotom was used in 12 patients, all women, aged 23 to 6 . years, from Psychiatric Department D of Sct. Hang Hospital. The indication for operation was in a 7 cases violently aggressive behaviour with assaults $a$ fellow patients and ward personnel, and/or $\frac{\pi}{6}$ marked tendency towards self-mutilation. All the 0 patients had for several years been treated by drugs and electrostimulation with short-lasting or no effect. In three of the patients, the amygdalotomy was supplemented with a basofrontal tractotomy as described by Knight (1965). A further six patients from other hospitals, operated on with the same indications, have not been included in this report.

\section{SURGICAL TECHNIQUE}

The stereotaxic operation was performed with the Leksell stereotaxic system (Leksell, 1966). All the procedures had to be carried out under general anaesthesia because of the mental state of the patients. The approach for the amygdalotomy was through frontal burr holes $3 \mathrm{~cm}$ from the mid-line, just in front of the coronal suture.

Before the operation positive pressure ventriculography was performed through the burr holes, 음 visualizing the temporal horn either by air or by $\bar{N}$ positive contrast (Conray ® meglumin $282 \mathrm{~J}$.). The latter gives a very satisfactory filling of the temporal 
horn if the ventriculography is carried out with the patient sitting up. The coordinates for the amygdala were calculated according to the specifications of Baird, Spiegel, and Wycis (1960).

The lateral coordinate was in most cases 20 to $22 \mathrm{~mm}$ from the mid-line. In seven of the patients the localization of the target was confirmed by recording the characteristic activity of the amygdala with a depth electrode, as described by Narabayashi et al. (1963). The lesion was made by bipolar electrocoagulation, using a high-frequency generator. The electrodes had a bare tip of $10 \mathrm{~mm}$; the interelectrode distance was $8 \mathrm{~mm}$. The temperature control was set at $65^{\circ} \mathrm{C}$, the time of coagulation was $45 \mathrm{sec}$. Two coagulations were made in each amygdala, one with the pair of electrodes in the frontal plane, and one with the electrodes in the sagittal plane. This produces a nearly cylindrical lesion, approximately $10 \times 10 \mathrm{~mm}$ in diameter. In all patients but one, bilateral amygdalotomy was performed in one session.

For the basofrontal tractotomies the ventriculogram was done in the same manner. The approach to the basofrontal region was through bifrontal burr holes centred $2 \mathrm{~cm}$ from the mid-line as far down as the frontal sinus would permit. The bipolar coagulations were fashioned to give a lesion of approximately $20 \times 20 \mathrm{~mm}$ on each side, extending back to $5 \mathrm{~mm}$ anterior to the plane of the tuberculum sellae, $10 \mathrm{~mm}$ over the floor of the anterior fossa, extending medially to $10 \mathrm{~mm}$ from the midline.

\section{PATIENTS}

Details of six patients are given in Table 1. They had all been institutionalized in a psychiatric hospital for several years. A feature common to them all was violently aggressive behaviour with assaultive episodes, and a tendency to self-mutilation. Diagnostically they were in different groups. Cases no. 1 to 5 were classified as personality disorders. One of them was adopted and her background is not known. The rest all had severe hereditary dispositions, with mental retardation, epilepsy, psychiatric and personality abnormalities in the family. They all had disharmonious and broken homes. One was of normal intelligence, the others were mentally sub-

TABLE 1

DETAILS OF SIX PATIENTS

\begin{tabular}{|c|c|c|c|c|c|c|c|}
\hline Case no. & $\begin{array}{l}\text { Age } \\
\text { (yr) }\end{array}$ & $\operatorname{Sex}$ & Diagnosis & Operation & $\begin{array}{l}\text { Depth recording } \\
\text { from amygdala }\end{array}$ & $\begin{array}{l}\text { Post-operative } \\
\text { result }\end{array}$ & $\begin{array}{c}\text { Observation } \\
\text { time after } \\
\text { last operation } \\
(\text { mth })\end{array}$ \\
\hline 1 & 30 & $\mathbf{F}$ & $\begin{array}{l}\text { Personality disorder, } \\
\text { mental retardation }\end{array}$ & $\begin{array}{l}\text { Cingulectomy } 1960 \text {, } \\
\text { amygdalotomy } \\
\text { May } 1968, \text { tracto- } \\
\text { tomy August } 1969\end{array}$ & - & $\begin{array}{l}\text { Unchanged after } \\
\text { amygdalotomy, ques- } \\
\text { tionable improvement } \\
\text { after basofrontal tract }\end{array}$ & 1 \\
\hline 2 & 31 & $\mathbf{F}$ & $\begin{array}{l}\text { Personality } \\
\text { disorder }\end{array}$ & $\begin{array}{l}\text { Cingulotomy } 1967, \\
\text { amygdalotomy } \\
\text { May } 1968\end{array}$ & $\begin{array}{l}\text { Moderate bilateral } \\
\text { spike activity }\end{array}$ & $\begin{array}{l}\text { Marked improvement, } \\
\text { no aggressions, } \\
\text { cooperative }\end{array}$ & 16 \\
\hline 3 & 23 & $\mathbf{F}$ & $\begin{array}{l}\text { Glioma of IVth } \\
\text { ventricle followed by } \\
\text { personality disorder }\end{array}$ & $\begin{array}{l}\text { Lobotomy 1965, } \\
\text { amygdalotomy } \\
\text { Aug. 1967, amyg- } \\
\text { dalotomy (reopera- } \\
\text { tion) Jan. } 1968\end{array}$ & - & $\begin{array}{l}\text { Marked improvement, } \\
\text { no aggressions, quiet, } \\
\text { cooperative }\end{array}$ & 21 \\
\hline 4 & 32 & $\mathbf{F}$ & $\begin{array}{l}\text { Psychomotor } \\
\text { epilepsy, reactive } \\
\text { psychosis, person- } \\
\text { ality disorder }\end{array}$ & $\begin{array}{l}\text { Lt.amygdalotomy } \\
\text { Dec. } 1965 \text {, } \\
\text { rt. amygdalotomy } \\
\text { April 1966, baso- } \\
\text { frontal tractotomy } \\
\text { Feb. } 1967\end{array}$ & $\begin{array}{l}\text { Marked spike } \\
\text { activity } \\
\text { Marked spike } \\
\text { activity }\end{array}$ & $\begin{array}{l}\text { Aggression markedly } \\
\text { improved afterfirst } \\
\text { amygdalotomy. } \\
\text { No hallucinations after } \\
\text { basofrontal tractotomy }\end{array}$ & 24 \\
\hline 5 & 26 & $\mathbf{F}$ & $\begin{array}{l}\text { Reactive psychosis, } \\
\text { personality } \\
\text { disorder }\end{array}$ & $\begin{array}{l}\text { Amygdalotomy } \\
\text { Sept. 1968, baso- } \\
\text { frontal tractotomy } \\
\text { June } 1969\end{array}$ & $\begin{array}{l}\text { Marked spike } \\
\text { activity, rt. amyg- } \\
\text { dala, slight spike } \\
\text { activity, lt. amyg- } \\
\text { dala }\end{array}$ & $\begin{array}{l}\text { Aggressions only slight } \\
\text { after amygdalotomy. } \\
\text { No aggressions or } \\
\text { hallucinations after } \\
\text { basof rontal tractotomy }\end{array}$ & 4 \\
\hline 6 & 58 & $\mathbf{F}$ & $\begin{array}{l}\text { Seq. cerebral } \\
\text { contusion }\end{array}$ & $\begin{array}{l}\text { Amygdalotomy } \\
\text { Nov. } 1968\end{array}$ & $\begin{array}{l}\text { Marked spike activity } \\
\text { rt. amygdala } \\
\text { moderate spike ac- } \\
\text { tivity lt. amygdala }\end{array}$ & $\begin{array}{l}\text { No aggressive episodes } \\
\text { postoperatively }\end{array}$ & 10 \\
\hline
\end{tabular}


normal. As they formed a rather inhomogeneous group, the case histories will be briefly reviewed.

\section{CASE 1}

She is a $\mathbf{3 0}$ year old woman. Her father was a mentally retarded alcoholic, who had spent several periods of time in prison. The parents were divorced when the patient was 3 years old. The patient is mentally retarded, went to a school for the mentally subnormal and spent most of her time in an orphanage for the subnormal.

She had nocturnal enuresis at least till the age of 8 . At 20 years old she had a grand mal seizure. Since the age of 19 she has spent most of her time in psychiatric hospitals, becoming progressively mentally unstable with episodes of dysphoria. During these periods she could be violently aggressive. There were two episodes of attempted arson. When she was 21 years old an open bilateral cingulectomy was done with doubtful and short-lasting effect. She was still explosively aggressive and self-mutilating. Electroencephalography (EEG) revealed spikes on photic stimulation, but was otherwise normal. Bilateral amygdala coagulation was done when she was 29 years old. Regrettably the neurosurgical case records have been lost, so no further details about the operation can be obtained. She made fewer assaults after this procedure, but was essentially unchanged in her behaviour with temper tantrums and self-mutilations. One year later a basofrontal tractotomy was made. The observation time (one month) is still too short to permit any conclusions about the result.

\section{CASE 2}

She is a 32 year old woman. Her father was diagnosed as a constitutional psychopath. One sister committed suicide; another sister is a schizophrenic. Several maternal relatives have epilepsy. She came from a disharmonious home; the parents were divorced. The patient is of normal intelligence. She was always sensitive, with a tendency to self-isolation. She was first admitted to a psychiatric department when 17 years old, with frequent admissions during the following years. Since the age of 27 she has been constantly in a psychiatric hospital. She is described as restless, withdrawn, with explosive episodes of aggression towards patients and staff. Self-mutilations with several attempted suicides are recorded. When she was 30 years old she had a bilateral open cingulectomy, with some temporary improvement. Bilateral amygdala coagulations were performed two years later. Depth recordings during the operation showed moderate bilateral spike activity in the amygdala. Since the amygdalotomy she has had no more aggressive episodes. She is still withdrawn and avoids emotional contact, but is helpful in the ward, running errands, etc. Post-operative observation was 16 months.

\section{CASE 3}

She is a woman aged 23 years Her father made several attempts at suicide. A sister has been admitted to a psychiatric department, diagnosis unknown. When she was 2 years old a benign glioma was removed from the IVth ventricle. Temper tantrums were described from the age of 3 years. Since then there were progressive behavioural abnormalities. First admission to a psychiatric department was at 12 years old, and she was constantly admitted from the age of 15 . Intelligence was in the lower normal range. She was characterized as intensely emotionally unstable, with frequent explosive episodes of vicious aggression and destruction, during which she would indiscriminately attack persons, throw available objects, or mutilate herself. At 17 years old a bimedian frontal lobotomy was done by the Poppen method, without any effect. A bilateral electro-coagulation of the amygdala was done when she was 21 years old. There was no effect of the initial lesions, which seemed to be too small. The procedure was repeated five months later with enlargement of the lesions. Over the years the EEG had been without abnormalities. An EEG with sphenoidal leads just before the operation showed a few left sphenoidal spikes of doubtful significance. Since the last operation there have been no further episodes of aggressiveness or self-mutilation. The patient is quiet and cooperative, she is receiving elementary school training and helping with various tasks in the ward. Observation time is $\mathbf{2 1}$ months after amygdalotomy.

\section{CASE 4}

She is a woman aged 32 years. She was adopted when 9 days old, and the family disposition is unknown Intelligence is within normal limits, but she has a dyslexia A normal primary school course was followed. Since the age of 12 years there have been behaviour disturbances with episodes of assault. She has worked as a wardhelpex for three years (from the age of 22 to 25 ), but has othere wise been in a psychiatric ward since the age of 17 . There were frequent periods of assault in which she was extremely dangerous to her surroundings, being a large and strong person. She had to be kept strapped down at intervals. During these episodes she mutilated herself, and she also seemed to have auditory hallucinations. There was good emotional contact during the nonpsychotic phases. She stated that the episodes were often accompanied by an ascending epigastric aura and sometimes olfactory hallucinations. She then heard threatening voices commanding her to attack people, destroy specified objects, or mutilate herself in various ways. She was intensely scared of the voices. There was a partial amnesia for the subsequent events, but she often remembered some of her excesses and was extremely regretful. Repeated EEGs were normal but on photic stimulation there was, on two occasions, generalized spiking and paroxysmal 3 to $4 \mathrm{~Hz}$ activity. Sphenoidal recordings were normal. It was felt that psychomotor seizures with a deep temporal lobe focus could not be ruled out, and permanent depth-electrodes were implanted bilaterally in the amygdala and the hippocampus. These revealed on several occasions spike-activity in the left amygdala and spikes of doubtful significance in the right amygdala. A left amygdala coagulation was therefore carried out. She was 28 years old at that time. After the operation there were only minor episodes of aggression. Her 
auditory hallucinations continued. She was still very scared of the voices but could mostly resist the hallucinatory commands.

Three months after the first operation a new depthelectrode was placed in the right amygdala. Marked spiking was recorded from the area (possibly secondary to the first electrode implantation), and a right amygdala coagulation was carried out. This did not change her condition. The voices continued to threaten her. She was not aggressive, but again had periods of destructiveness and self mutilation with severe depressive reactions.

It was decided to carry out a basofrontal tractotomy in an effort to relieve her distressing symptoms. This was done one year after the first amygdalotomy.

After the last operation her auditory hallucinations disappeared, and she became increasingly better. She was discharged to day-hospital status nine months after the operation. She is now employed as a packer in the hospital stores and lives in town with an elderly man. The observation time since the last operation is two years. She has had no psychotic episodes since then, but can still have moderate verbal outbursts.

CASE 5

She is a 26 year old woman. One sister, probably a psychopath, is in a mental institution. The parents are divorced. The patient's intelligence may be within normal limits, but functionally she is mentally retarded. Since the age of 20 she has been almost constantly in psychiatric hospitals. She had periodic dysphorias with suicidal attempts and self mutilations, auditory hallucinations with commanding, threatening voices, and possibly visual hallucinations. The hallucinations were accompanied by fear, leading to violent episodes with aggressions, window-breaking, etc. She also had anankastic-ritualistic compulsions. The EEG was slightly abnormal with diffuse 4 to $6 \mathrm{~Hz}$. activity, occasionally with sharp waves. A bilateral amygdala coagulation was performed. During the operation depth recordings revealed marked spike activity from the right amygdala and only isolated spikes on the left side. After the amygdalotomy she was markedly better with no hallucinations for two months. Her symptoms then recurred. The aggressions were less prominent, but otherwise the condition deteriorated to the pre-operative level. A basofrontal tractotomy was made nine months after the amygdalotomy. She has since then been remarkably improved with stable behaviour. She has been discharged to day-hospital status and works in the hospital as a ward assistant.

Observation time since the last operation is only four months.

\section{CASE 6}

She is a woman aged 58 years. There was no previous disposition to psychiatric illness. When she was 43 years old she sustained cerebral contusion in a motor accident. She remained unconscious to somnolent for three weeks. Steady amelioration in her condition occurred during the first year, but it has been stationary since then. She is now deeply demented, disorientated in time and place.
She has frequent episodes of aggressive behaviour with destructive tendencies. Bilateral amygdala coagulation was done in one session. The ventriculogram showed a severe dilatation of the lateral and IIIrd ventricles. The left temporal horn was normal, the right slightly dilated. Depth electrode recording from the amygdala showed marked spike activity bilaterally. After the amygdalotomy she has been much more quiet, with occasional shouting, but no aggression. Post-operative observation has been over 10 months.

\section{CASES 7 TO 12}

These are six chronically schizophrenic women (Table 2). Their ages were between 35 and 66 years at operation. Their symptoms appeared between the age of 17 and 20 years in five of the cases, in one of them at the age of 43 . They were all severely affected. In four of the patients no verbal contact was possible, in two of them there was at times a superficial contact. They were all hallucinated, violent, threatening, and aggressive, throwing objects, and attacking staff and fellow patients. Two of them were directly dangerous. One was periodically self-mutilating. Four of them had had bifrontal lobotomies performed 15 to 20 years previously, and in three of them the lobotomy had been repeated. The operations had no or very short-lasting effect. One of the patients had a symptomatic epilepsy after a repeat lobotomy.

Because of technical errors, depth recordings from the amygdala were obtained in only three of the six patients. In two of the patients, who both had previously had a lobotomy, there was marked spike activity. The third, who had not been operated before, had normal findings. In all six patients the amygdalotomy had a marked effect on their aggressions. One of the two patients who previously made dangerous assaults (no. 7) is now quiet and cooperative. She is out of bed all day, doing various tasks in the ward, and doing them well. The other patient (no. 8) is out of the bed most of the day, making clothespegs. During the last six months she has deteriorated somewhat and can be dysphoric with tendencies towards aggressiveness. Reoperation is contemplated.

Patient no. 9 died recently, two years after the amygdalotomy, of unrelated causes. Unfortunately the brain was not preserved. Neither she nor the three remaining patients in this group have had any aggressive episodes since the amygdalotomy, but they are of course still totally incapacitated by their chronic schizophrenic symptoms. One of them (no. 12) is still periodically severely self-mutilative, and a basofrontal tractotomy is contemplated.

\section{DISCUSSION}

None of the 12 patients seems to be in any respect worse after the amygdalotomy or the basofrontal tractotomy. Patients 1 to 5 had pre- and postoperative psychological tests, and no deterioration in their scores was found. None of the patients had post-operative symptoms resembling the KlüverBucy syndrome (Terzian, 1955) seen after more 
TABLE 2

DETAILS OF SIX CHRONICALLY SCHIZOPHRENIC PATIENTS

\begin{tabular}{|c|c|c|c|c|c|c|c|}
\hline Case no. & $\begin{array}{l}\text { Age } \\
(y r)\end{array}$ & $\operatorname{Sex}$ & Diagnosis & Operation & $\begin{array}{l}\text { Depth recording } \\
\text { from amygdala }\end{array}$ & $\begin{array}{c}\text { Post-operative } \\
\text { result }\end{array}$ & $\begin{array}{c}\text { Observation } \\
\text { time after } \\
\text { last operation } \\
(y r)\end{array}$ \\
\hline 7 & 35 & $\mathbf{F}$ & Schizophrenia & $\begin{array}{l}\text { Lobotomy } 1952 \text {, } \\
\text { repeat lobotomy } \\
\text { 1954, amygdalotomy } \\
\text { Oct. } 1966\end{array}$ & $\begin{array}{l}\text { Marked bilateral } \\
\text { spike activity }\end{array}$ & Noaggressions & 3 \\
\hline 8 & 45 & $\mathbf{F}$ & Schizophrenia & $\begin{array}{l}\text { Lobotomy } 1946, \\
\text { repeat lobotomy } \\
1952 \text {, amygdalotomy } \\
\text { Oct. } 1966\end{array}$ & $\begin{array}{l}\text { Marked spike } \\
\text { activity, r. amygdala, } \\
\text { moderate spike } \\
\text { activity, l. amygdala }\end{array}$ & $\begin{array}{l}\text { Occasional aggressions, } \\
\text { reoperation considered }\end{array}$ & 3 \\
\hline 9 & 66 & $\mathbf{F}$ & Schizophrenia & $\begin{array}{l}\text { Lobotomy } 1948 \text {, } \\
\text { repeat lobotomy } \\
1951 \text {, amygdalotomy } \\
\text { April } 1967\end{array}$ & - & No aggressions & $2 \frac{1}{2}$ \\
\hline 10 & 56 & $\mathbf{F}$ & Schizophrenia & $\begin{array}{l}\text { Lobotomy } 1946 \text {, } \\
\text { amygdalotomy } \\
\text { April } 1967\end{array}$ & - & No aggressions & $\begin{array}{l}\text { Died } 2 \text { years } \\
\text { after operation }\end{array}$ \\
\hline 11 & 63 & $\mathbf{F}$ & Schizophrenia & $\begin{array}{l}\text { Amygdalotomy } \\
\text { Oct. } 1968\end{array}$ & No abnormality & No aggressions & 1 \\
\hline 12 & 39 & $\mathbf{F}$ & Schizophrenia & $\begin{array}{l}\text { Amygdalotomy } \\
\text { Oct. } 1968\end{array}$ & - & $\begin{array}{l}\text { No aggressions, still } \\
\text { self-mutilations, } \\
\text { basofrontal tractotomy } \\
\text { considered }\end{array}$ & 1 \\
\hline
\end{tabular}

extensive ablation of the mesial temporal structures. This is in accordance with the experience of Narabayashi et al. (1963) and of our own series of patients with psychomotor epilepsy, in which 11 patients had bilateral amygdala coagulation. Patient no. 1 is severely retarded mentally. The minimal effect of the amygdalotomy in this case corresponds to the experience of Narabayashi et al. (1963) and Heimburger et al. (1966) in similar pátients, and amygdalotomy should probably not be considered to counter aggression in the patient with marked mental subnormality. The observation time in patient no. 1 is still too short to permit any conclusion regarding the effect of basofrontal tractotomy in such cases.

In the rest of the patients, episodes of aggression, hostility, and destructiveness were markedly improved or disappeared after the amygdalotomy. It is probable that the behavioural abnormalities in patient no. 4 were referable to a psychomotor epilepsy, but the results of the operations have not been dependent on the presence or absence of spikes from the amygdala in depth electrode recordings. It should, however, be noted that six of the seven patients in whom depth recordings were obtained had definitely abnormal findings with bilateral spike activity. Hallucinations did not seem to be significantly influenced by the amygdalotomy. These did, however, lose much of their threatening character, and were accompanied by less fear than before the operation. Fear and rage reactions can be provoked by amygdala stimulation in the laboratory animal as demonstrated in the experiments by Ursin (1960). Feelings of fear and apprehension, provoked by stimulation of the amygdala during temporaf lobe operations in patients with psychomotor epilepsy, are a well known phenomenon. That rage and violently aggressive behaviour can also be elicited by stimulation of the amygdala in patients has recently been demonstrated in a striking manner by Mark, Ervin, and Sweet (1969). They were able to provoke explosive episodes of assault by telemetric stimulation of the amygdala in a patient with psychomotor epilepsy in whom such occurrences had been part of her spontaneous seizure pattern. There thus seems to be ample evidence indicating that the amygdala is an important part of the cerebral pathways involved in the manifestations of aggressive behaviour.

The reactive psychosis with hallucinations which persisted after the amygdalotomy disappeared in patients no. 4 and 5 after the basofrontal tractotomy (Knight, 1965) and so did the auto-mutilative tendencies. The lesion here involves the substantia innominata overlying area 13 of the medial orbital frontal cortex. Lesions in this region were found by Knight to be the therapeutically effective part of the orbital undercutting operation. This same region is 
one of the important links in the orbital-frontaltemporal-amygdalar circuit, which is one of the main components of the fronto-limbic-hypothalamic/ midbrain behavioural axis proposed by Livingston (1969).

In the amygdalotomy and the basofrontal tractotomy, our interventions seem to affect different levels of the same circuit. It would seem from our present small material that aggressive-destructive tendencies are best influenced by the amygdalotomy, while the basofrontal tractotomy is more effective against hallucinations and auto-mutilative behaviour. It is, however, possible that the abolition of these latter manifestations may require operation at both levels, since in the patients referred here the basofrontal tractotomy was always preceded by an amygdalotomy.

\section{REFERENCES}

Baird, H. W., Spiegel, E. A., and Wycis, H. T. (1960). The variability in the extent and position of the amygdala. Confin. neurol. (Basel), 20, 26-36.

Erwin, F. R., and Belsasso, G. (1964). Stereotaxic treatment of temporal lobe epilepsy. Neurophysiologic and behavioral observations. In Homenage en el XXV Aniversario Profesional of Dr. M. Velasco-Suarez. Editorio Pregeso: Mexico City.

Falconer, Murray A. (1965). The surgical treatment of temporal lobe epilepsy. Neurochirurgia, 8, 161-172.

Gibbs, F. A. (1958). Abnormal electrical activity in the temporal regions and its relationship to abnormalities of behaviour. Res. Publ. Ass. Res. nerv. ment. Dis., 36, 278-294.
Heimburger, R. F., Whitlock, C. C., and Kalsbeck, J. E. (1966). Stereotaxic amygdalotomy for epilepsy with aggressive behaviour. J. Amer. med. Ass., 198, 741-745.

Hill, D. (1952). EEG in episodic psychotic and psychopathic behaviour. Electroenceph. clin. Neurophysiol., 4, 419-442.

Hughes, J. R., and Schlagenhauff, R. E. (1961). Electroclinical correlation in temporal lobe epilepsy, with emphasis on inter-areal analysis of the temporal lobe. Electroenceph. clin. Neurophysiol., 13, 333-339.

Knight, G. (1965). Stereotactic tractotomy in the surgical treatment of mental illness. J. Neurol. Neurosurg. Psychiat., 28, 304-310.

Leksell, L. (1966). Some principles and technical aspects of stereotaxic surgery. Pain. Edited by R. S. Knighton and P. R. Dumke. Little, Brown: Boston.

Lennox, W. G. (1960). Epilepsy and Related Disorders. Vol. 2. Little, Brown: Boston.

Livingston, K. E. (1969). The frontal lobes revisited. Arch. Neurol. (Chic.), 20, 90-95.

MacLean, P. D., and Delgado, J. M. R. (1953). Electrical and chemical stimulation of fronto-temporal portion of limbic system in the waking animal. Electroenceph. clin. Neurophysiol., 5, 91-100.

Mark, V. H., Ervin, F. R., Sweet, W. H., and Delgado, J. (1969). Remote telemeter stimulation and recording from implanted temporal lobe electrodes. Confin. neurol. (Basel), 31, 86-93.

Milner, B. (1958). Psychological defects produced by $t: m-$ poral lobe excision. Res. Publ. Ass. Res. nerv. ment. Dis., 36, 244-257.

Narabayashi, H., Nagao, T., Saito, T., Yoshida, M., and Nagahata, M. (1963). Stereotaxic amygdalotomy for behaviour disorders. Arch. Neurol. (Chic.), 9, 1-16.

Papəz, J. W. (1937). A proposed mechanism of emotion. Arch. Neurol. Psychiat. (Chic.), 38, 725-743.

Terzian, H., and Ore, G. D. (1955). Syndrome of Klüver and Bucy reproduced in man by bilateral removal of the temporal lobes. Neurology (Minneap.), 5, 373-380.

Ursin, H. (1960). The temporal lobe substrate of fear and anger. Acta psychiat. neurol. scand., 35, 378-396.

Værnet, K., and Andersen, R. Stereotaxic amygdalotomy in psychomotor epilepsy. Confin. neurol. (Basel). (To be published). 